\title{
The Existence of the Word Tabe in WhatsApp
}

\author{
Hastianah $^{1}$, Yusniati N. Sabata ${ }^{2}$, Ramlah Mappau ${ }^{3}$ \\ Language Center, South Sulawesi, Jl. Sultan Alauddin Km 7 Tala Salapang ${ }^{13}$, Muhammadiyah \\ Luwuk University, Jl. K.H. Ahmad Dahlan, Luwuk Banggai, Central Sulawesi 94711, Indonesia ${ }^{2}$
}

\{hastianahnurdin@gmail.com\}

\begin{abstract}
The word tabe can be found in the Bugis and Makassar tribes. This word is usually used to ask a guest permission. The use of the word tabe is closely tied to the existence of local customs, conditions, and conversation situations. In communication or speech events, the word tabe is very difficult or even heavy to pronounce at this time, only certain speakers usually use the word to maintain politeness. The word tabe is not only used in face-to-face communication, but has been used in social media, such as WhatsApp. This research is a qualitative descriptive study using a sociolinguistic paradigm, which describes and describes the use of the word tabe in social media (WhatsApp). This research uses listening, engaging, and tapping techniques. Data analysis described the correlation of language choice and relating it to power and status. The purposed of this study is to describe or provide an overview of language variations regarding power and status in the WhatsApp group. The result of this research is that the word tabe can be used to state: 1) request for permission, such as tabe $\mathrm{Bu}$, Nur Alisa Salsabila cannot enter school today because of illness, 2) requests, for example tabe can borrow reports from last year, 3) orders, for example Assalamualaikum, delivered to the teacher / guardian kls to convey the students tomorrow Friday to bring an Android cellphone for the simulation activity of PAS Odd Tp 2019/20 tabe, 4) delivery of information, for example tabe Bu adami full name of the mayor of Parepare?, 5) politeness, usually followed by body gestures, namely looking down, bending over, and opening the palms that are slightly swung forward parallel to the head followed by the word tabe, but in WhatsApp this is not the case, only using varied words are used before stating something or after stating something that the partner may or may not agree with. Thus, the word tabe has experienced a shift in the younger generation, there is a correlation in language choice caused by the relationship between power and status.
\end{abstract}

Keywords: tabe, existence, language variety, Bugis, Makassar.

\section{Introduction}

Community as language speakers on social media on WhatsApp is always growing and developing. This influences the use of the language. As is appropriate, something that is alive develops as well. In the process of development, language undergoes changes and new elements are created. There is also particular element is getting faded. All this happens in accordance with the movements and dynamics of society and its users.

The word tabe can only be found in the Bugis and Makassar tribes. This word is used to ask permission from guests. The use of the word tabe is closely tied to the existence of local customs, conditions of politeness, and conversation situations. In communication or speech events, at this time the word tabe is very difficult or even heavy to pronounce, even often as an 
abbreviation and is used as a negative connotation to become tanja bembe (goat face). Only certain circles and speakers continue to use the word to protect its politeness. Millennial young people rarely use the word tabe moreover on social media at present time. The word tabe is only used when it comes to people who are sensitive to customs and when someone will pass in front of older people who are respected. The use of this word is followed by gestures and hands on the hands at the sides of the body to show politeness. The word tabe is not only currently used in face-to-face communication, but it is also used in social media, such as WhatsApp

In communicating via WhatsApp, of course, there are parties who act as Conveyors of intent and Receivers of intent. In order for good communication, the two parties must be able to work together well. Good cooperation can be created by paying attention to whom is invited to communicate, the situation, place, contents of the speaker, and the media used in communication. Conversations in WhatsApp consist of two dimensions, namely the linguistic dimension and the social dimension. These two dimensions are very closely related, complementary to one another. The linguistic dimension can be observed, heard, and analysed, while the social dimension can only be understood why speaking is like switching codes. In this paper, the linguistic dimension refers to the physical dimension in the form of linguistic units.

WhatsApp offers a simple messaging and calling experience, is an instant messaging app, is secure and reliable, and is available on phones all over the world. In situations like this, communication on social media on WhatsApp, speakers who only know their mother tongue as their first language, become bilingual with Indonesian as their second language. Increasingly intensive communication with a bilingual person will bring about changes and result in a symptom of language, both code mixing and code switching. The same thing is stated by Nababan that if we see someone's conversation using two languages in their interactions with other people, they are bilingual in the sense that they practice bilingualism which is called bilingualism [1]. Indonesian language users have different backgrounds in the mother tongue, which has made the Indonesian language varied and diverse, so that it affects each other with the local language. These result a linguistic problem called alternation

Based on the description above, what needs to be answered in this study is how the existence of the word tabe on WhatsApp using the sociolinguistic interaction paradigm. The goal to be achieved is to describe the use of the word tabe in WhatsApp, which includes problems with requests for permission, requests, conveying information, and expressing politeness [2]. Through this research, it is expected that it can add insight and become input for the development of linguistic theory in general and sociolinguistic theory in particular. Practically speaking, language users can understand cultural culture in everyday life and society.

Yassi states that the social phenomenon is communicative strategies that have a number of interactional functions, namely situational switching and metaphorical switching [3]. Situational code switching is a code change that accompanies a topic or participant change. This code switching is done to respond to the change of language used from standard forms of language to non-standard languages such as the language used for everyday communication in casual situations.

Furthermore, in analysing the parts of the conversation that occur, the theory proposed by Manyambeang is used. Manyambeang mentions three kinds of pronouns in Makassar, namely (1) personal pronouns, (2) second pronouns, and (3) third pronouns. Personal pronouns in Makassar can be described as follows. (1) The first personal pronoun is divided into two types, namely the first person is singular, and the first person is plural. The first personal is single like nakke 'me' -ku 'ku', -ku '-ku-, and -kid' me ', while the first persona is plural like ikatte ngaseng' we all 'and he ngaseng' you all '. (2) Second person pronoun. The second singular persona has several forms, namely you / ikau 'you', nu, --nu, and -ko 'you / you' -ta 'us, and -kik' we / salute 
'. Meanwhile (3) the third persona consisted of two kinds of singular third persona, namely the third persona free form and the third persona bound form. The free form is represented by the word ia 'he/she' and the bound form is denoted by -na, na- 'he/she', and i 'all of us'. In addition, the pronoun persona of Manyambeang describes the syntactic structure and particles. The syntactic structure can be seen in two ways, namely (1) the location of the structure, and (2) the scope of the structure, while the actual particle is in the form of clitics because it always lies at the end of the word it follows, for example -ka, -ma, -sa, -mi., Ji. The particle -ka 'kah' is the particle used in interrogative sentences. Particles -madanji 'already / lah' are particles that are used in sentences which mean 'already' or 'lah'. The particle -sa is the particle used in the command sentence which is rather subtle while the - mi particle is used in the news sentence [4].

Basically, a conversation in a community on WhatsApp consists of two dimensions, namely the linguistic dimension and the social dimension. These two dimensions are very closely related, complementary to one another. The linguistic dimension can be observed, heard, and analyzed, while the social dimension can only be understood why speaking is like switching codes. In this paper, the linguistic dimension refers to the physical dimension in the form of linguistic units.

The linguistic dimension consists of two parts, namely linguistic dimension and interactional social dimension. There are two types of code-switching dimensions, namely: a) Syntax categories, and b) Types of code switching. The linguistic dimension of code switching in the syntactic category consists of several forms, namely: word order, word form, and intonation

\section{a. Linguistics Dimension Form}

The dimension can be divided into two types, namely: a) Syntax categories, and b) Types of code switching. The linguistic dimension of code switching in the syntactic category consists of several forms, namely: word order, word form, and intonation.

The Lenders in Taha argue that two languages make contact with each other, mixing and borrowing lexemes, grammatical categories are difficult to avoid [5]. Which linguistic features diffuse is largely determined by the linguistic situation of the language in contact with each other. People tend to indirectly adjust their speaking habits with those with whom they interact.

\section{b. Social Dimension Form}

The use of everyday language is always tied to the situation of the social dimension and interpreted in the situation. The conversation function in WhatsApp, in a communication event produces speech. A series of utterances forms discourse. Brown and Yule suggest that discourse is a series of utterances resulting from communicative acts in actual situations of language use [6], [7]. In this case, discourse requires social context, non-linguistic context, and linguistic context.

\section{Research Methods}

The interactional sociolinguistic approach in analysing discourse is based on sociology and linguistics. An interdisciplinary approach is applied to this approach in analyzing discourse [8], [9]. Sociology involvement is more focused on efforts to observe the relationship of an utterance with various social facts that exist and are embraced by a society, while the linguistic approach 
is revealed in language media. In everyday life, the existence of an utterance cannot be completely separated from social factors and verbal meaning [10].

\section{Results and Discussion}

Conversation in community using the word tabe on WhatsApp consists of two dimensions, namely the linguistic dimension and the social dimension. These two dimensions are very closely related, complementary to one another. It is the linguistic dimension that can be observed, documented, and analyzed while the social dimension can only be understood why speaking is like switching codes [11]. In this paper, the linguistic dimension refers to the physical dimension in the form of linguistic units.

This research will reveal how the sociolinguistic interactions of the existence of the word tabe on WhatsApp can be used to state: a) request permission, b) request, c) order, d) convey information, and e) express politeness.

a. Request Permission

The word tabe can be used to express a request for permission. There are two possibilities for this permission statement to be accepted or not. The word tabe with the aim of requesting permission can be addressed to friends, teachers, and family. This can be expressed in the following WhatsApp screenshots.

1) Assalamualaikum, tabe Ma'am. I asked if you could let permission for Nur Insana to not to go to school today since she has an appointment in the hospital. Thank you

2) Assalamualaikum. Good evening ladies and gentlemen. Tabe, could you please send me photo of your identity card for the Check-in ticket. You can send it here or through personal messaging on WhatsApp. Thanks

3) Tabe, please list the names who want to take the bus back to Makassar on the $28^{\text {th }}$ tonight [12],[13].

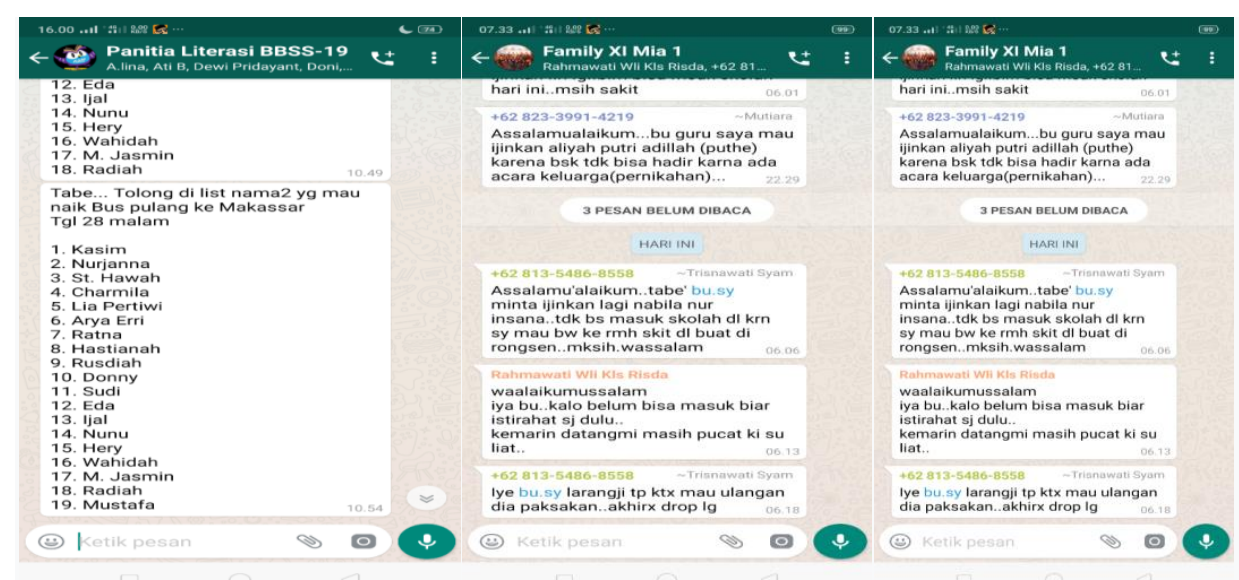

The word tabe in sentence (1) states the request for permission between the parents of students to the teacher. This does not consider which one is older between the parents and the teacher or vice versa. The teacher is older than the parents of the students. The word tabe states that the request for permission is subtle to the teacher. It can be seen in the word 'saya' ask for 
ijinka (-ka) indicating the singular first-person pronoun - ak 'I'. Furthermore, in sentence (2) states the general request for permission is addressed to ladies and gentlemen. The word tabe states requesting permission on the word can send a photo ID (-ta) denotes the second person pronoun 'we'. In sentence (3) the subtle request for permission uses the word tabe in the speaker towards the speech partner so that the names who want to take the bus are expected to be listed. b. Request

The word tabe can be used to express a request to a person, its purpose to ask for hope and apologize. This can be showed in the following WhatsApp:

Data (4). aslkm tabe, diundangki semua ya Asslkm tabe, all are invited diundang $\underline{k i}(-k i)$ merupakan pronomina persona kedua $-k i$ 'kita/sapa hormat'. The word tabe in sentence (4) stated a hoping request that addressed to friends, teachers, and family. The word tabe is used for expecting the presence of someone as can be seen: diundang $\underline{k i}(-k i)$. It is kind plural personal pronoun -ki "you", kita/for respecting.

Data (5). Assalamualaikum

Dear (friends) the committee of the Children Literacy Reading Book Competition for all levels. It is hoped that be present at 10.00 tomorrow for the presentation of prizes and guidance to the winners.

We are sorry that the schedule was advanced on Kabak instruction. Tabe. Please be advised.

The word tabe in the last sentence (5) showed on apologize addressed to friends for respecting the fellow friends.

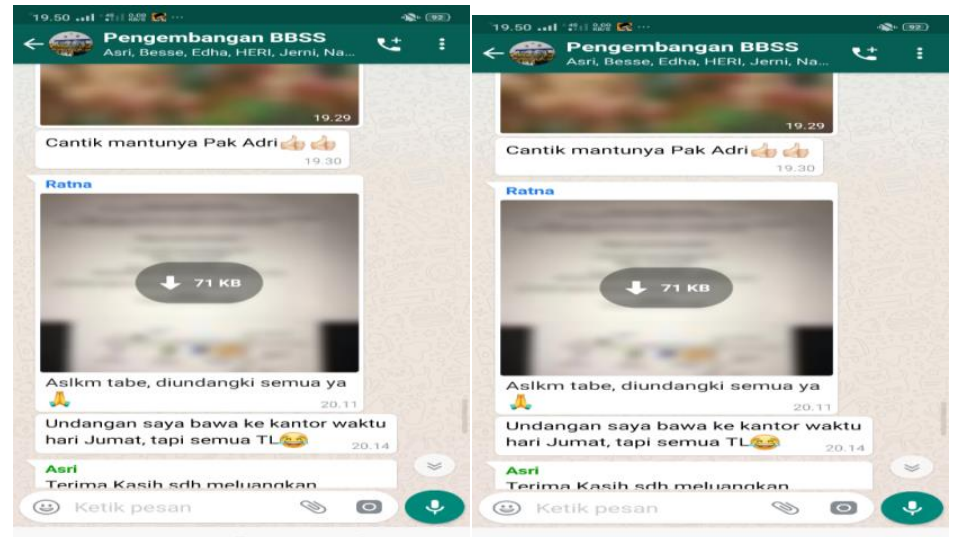

c. Giving Information

Word has an important role in Makassar social life. It can be seen on the using the word of tabe extends to social media than ever before. The using of tabe in social media as kind of spoken speech that rewrote although not many users, it is only used by people that feel sensitive to politeness. This word can be found in the beginning, middle, or end of the sentences. This word implies the politeness of Bugis Makassar society as a kind of giving information, such when conveying information to the older or younger, or to the same age. It means that, in generally the word is used and addressed to among older people or adults, while the teenagers 
are rarely found. The word as politeness sign has different functions based on the speech or sentences used.

Giving information that carried out by younger to older, and someone who has higher position used declarative or interrogative sentences.

Data (6)

Data (7)

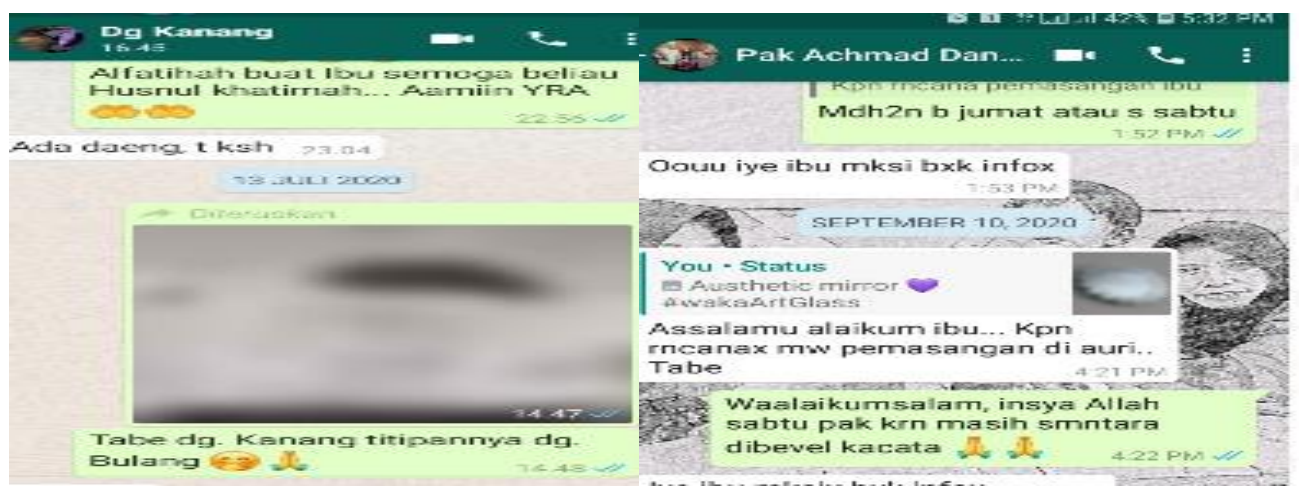

(8) Tabe bu, salah kumpulka beng software bkdku

Tabe bu, I gathered the wrong bkd software.

(9) Tabe Bunda Insya Allah besok malam saya ke rumah.

Tabe bunda, God willing, I will come to your home tomorrow night.

(10) AssalamualaikumIbu... kapn rencananya mw pemasangan di auri Tabe. Assalamualikum Ibu ... When the plan to install it in auri, Tabe.

(11) Assalamualaikum ... Tabe.... Assalamualaikum . . Tabe

(12) Tabe sy save bbrp.....

Tabe, I want to save several. . .

Speech (8) is used by someone to the staff who is proposing his promotion. He communicates with someone which elder than himself. He uses an interrogative sentence and needs a long answer from the interlocutor. Speech (9) is used by a younger speaker. It is indicated of the using of daeng greeting. Likewise, speech (8) that also utters by younger to older that is marked by the greeting of bunda. Then, the speech (4) that described previously is used by the speaker that has equal social status which indicated by the using of pronoun $-k i$.

\section{d. Politeness}

The synonym of the word tabe or the word tabe itself is; excuse me, apologize, and, permission. In English, excuse me has similar meaning namely, giving respect to each other as the evidence of politeness in speaking behavior. Polite speech communication that begins with the word tabe, even though the interlocutors is in unstable emotional condition, the word of tabe is still a consideration to maintain the communication that under control from impoliteness speech. A speech which is marked with the word tabe can create harmony relationships.

The word tabe is a symbol is used to respect for people who are older, younger, and equal age, or have equal social status or higher position. In communication, there are some rules that should be obeyed in order the communication could be well and polite. Politeness in non-tagnent situation can be marked by using word tabe. The use of tabe is not regulated, whether in the beginning, middle, or the end of sentences, it can be seen below: 


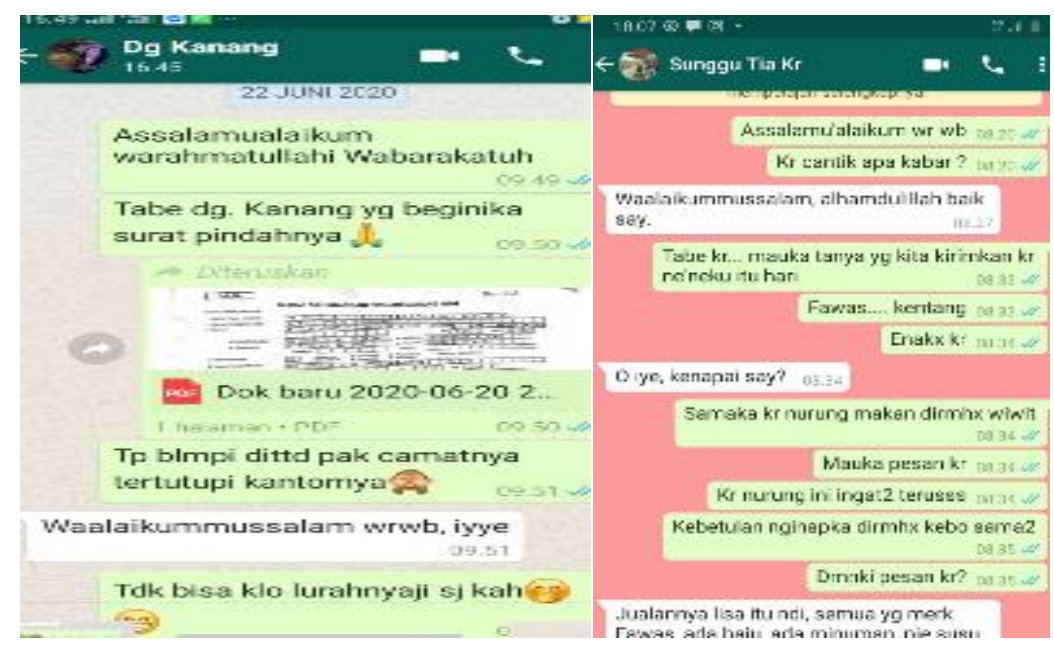

(15) Tabe Bu. Ada kosong galongta

Tabe $\mathrm{Bu}$. Is there your (-ta) empty gallon

(16) Tabe Pak nasir libur mahasiswa besokkah pak? Ada acara mauled

Tabe, sir Nasir, will the students have holiday tomorrow? There is a maulid event

(17) Tabe yasinan dimulai jam berapa apa tetap seperti biasa sudah salat isya.

Tabe, What time does Yasinan start, still as usual, after Isya prayer?

(18) Tanya....tabe besok upacara di mana $n$ pakaian korpri atau adat? Mohon kejelasan

Ask question. . .tabe, where is the ceremony held, and wear korpri or traditional clothes? Please clarify it.

Even though, the word tabe is also used by millennials on social media, such as in speech (1) to maintain politeness, speakers use the word tabe before showing something. The word tabe is used when the speaker wants/will (to) take an item close to someone, while the position that wants to take it is blocked by the partner's speech, such as the gallon courier who wants to take an empty gallon, as in speech (15). In addition to the word tabe as conversation starters, there is also a sign of politeness with the word - $t a$. The word - $t a$ is a form of courtesy that can be contrasted with $-n u$ (an impolite form). From the above example, the word tabe is generally used as a conversation starter to maintain politeness or politeness. The use of the word tabe, as in data (17), which performs a celebration of disseminating information and politely asks those who wish to participate in the yasinan event on time, namely after the evening prayer. Indirectly hopes that those who want to join the yasinan will arrive sooner or on time and do not feel forced to come on time.

\section{e. Command}

The word tabe is also found in the form of a imperative sentence. The use of the word tabe, makes a imperative sentence the center of attention and makes the imperative sentence smoother. The people who are ordered do not feel objected, humiliated, and immediately do what is ordered, as in the following speech. 

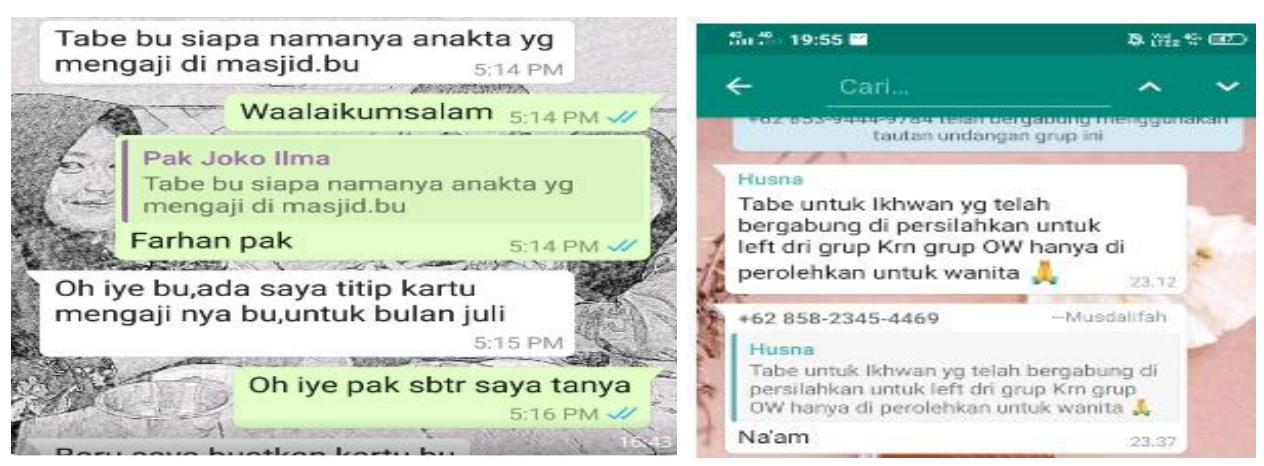

(19) Tabe, Admin tolong ditambahkan

Tabe, admin please add

(20) Tabe, kak, mau juga ditambahkan bingkai seminar Tabe untuk ikhwan yang telah bergabung dipersilahkan untuk left dr group Krn group OW hanya diperbolehkan untuk wanita.

Tabe, sis, would you like to also add a frame for the seminar, tabe. For brothers who have joined are allowed to leave the group because the OW group is only for women.

(21) Assalamualaikum Tabek, buat penulis buram gel. 2 tahun 2019, agar segera memasukkan

Assalamualaikum Tabek, for buram writers gel. 2 of 2019, has to submit paper immediately.

(22) Tabeka kalua sampaika Once kita Tanya sjaka kalua ada yang dikirim dari kampong suruh jemput di Tabaria.

Tabeka when I arrived Once please tell if there something was sent from the village, told to pick up in Tabaria.

The word tabe in imperative form is generally also used at the beginning of a speech as an opening conversation, it is used either older and the older and the younger.

\section{Conclusion}

The word tabe can appear at the beginning, middle and end of a sentence, and it is used to express: 1) request for permission 2), request, 3) command, 4) convey information 5), politeness. There are various types of the tabe used as an opening speech, and some are used after greeting. This word is used in certain circles with regard to age and social status.

\section{References}

[1] Nababan, P.W.J. 1993. Sosiolinguistik (Suatu Pj.gantar). Jakarta: Gramedia Pustaka Utama.

[2] J. P. Spradley, Metode Etnografi. Yogyakarta: Pustaka Pelajar, 2007.

[3] Yassi, Abdul Hakim. 2008. Tren Perilaku Bertutur Kaum Elit di Makassar Analisis Fungsi Alih Kode (Code Switching) dan Campur Kode (Code Mixing) Antara Bahasa Indonesia Dan Bahasa Inggris. (Budi Bahasa). Ujung Pandang: Badan Pj.erbit UNM

[4] Manyambeang, A. Kadir. et al. 1996. Tata Bahasa Makassar: Jakarta: Pusat Pembinaan dan Pj.gembangan Bahasa Departemen Pj.didikan dan Kebudayaan. 
[5] Taha, Zainuddin. 1985. Satu Wacana dua Bahasa: Faktor-Faktor Sosiolinguistik Alih

[6] Kridalaksana, Harimurti. 1985. Tata Bahasa Deskriptif Bahasa Indonesia: Sintaksis. Jakarta: Pusat Pembinaan.

[7] Kridalaksana, Harimurti. 2001. Kamus Linguistik. Jakarta: PT Gramedia.

[8] Rani, Abdul. 2006. Analisis Wacana Sebuah Kajian Bahasa dalam Pemakaian.Malang Jawa Timur: Bayumedia Publishing.

[9] Sumarsono. 2013. Sosiolinguistik. Yogyakkata: SABDA (Lembaga Studi Agama, Budaya dan Perdamian).

[10] Verhaar, J.W.M. 2006. Asas-Asas Liguistik Umum. Yogjakarta: GADJAH MADA UNIVERSTY PREES.

[11] Kode Bahasa Bugis-Bahasa Indonesia Ujung Pandang: Universitas Hasanuddin. (Disertasi).

[12] https://www.kompasiana.comfikriyyah57148/5d7db39f0823021865058d3/bahasa-jawa-ataubahasa-indonesia-dulu (diakses pada 8 Desember 2019).

[13] I. Abdullah, Konstruksi dan Reproduksi Kebudayaan. Yogyakarta: Pustaka Pelajar, 2015. 